\title{
TRAGEDY/IRONY
}

\section{A Reflection on Engaged Poetry and Time}

$\bigcup$ nlike a few decades ago, today-safe in our privilege-we, the people of the western culture, are allowed to protest. Irrespective of the brutality of the riot police and despite evident instances of the abuse of justice, the consequences of participation in peaceful demonstrations are incomparably less serious than it was the case in the early 1950 s, 60 s or even 80 s. And yet it would be impossible not to notice the profundity of the abyss between the palpable reality of desperate acts of self-immolation and the safety of Facebook-based philippics, between the individual tragedies of dying hunger strikers and the "intimate revolts"1 of those who-having much too much to lose-speak out against the "collapse of essential values" in the serene sanctuaries of their homes. The tragedy of the irony of the self-fashioned righteousness seems to match the irony of the real tragedies: the (post)modern hamartia seems to be well illustrated by the difference between two musical interpretations of Ernest Bryll's disconcerting confessional poem "Niosę jeszcze swe wiersze" ["I Still Carry My Poems"], first arranged and performed in the 1980s by a Polish bard, Tomek Opoka, and then reinterpreted and reinvented in 2009 by the a cappella group Banana Boat, whose version was included in an album created by Piotr Bakal in memory of the blind singer. The present reflections, therefore, address the phenomenon of the ironic protest, in which self-made heroes thrive, and tragic protesters become invisible, their humanity transformed into an icon.

Let me illustrate this with a brief analysis of the poem, whose simultaneous simplicity and sublimity make it one of the most

1. I took the liberty of borrowing this term from Julia Kristeva, who developed the concept in her 2003 book Intimate Revolt. The Powers and Limits of Psychoanalysis, published by the Columbia University Press.
Pawet Jędrzejko RIAS Managing Editor University of Silesia in Katowice Poland

(iD 
dramatic expressions of an existential dilemma that any ordinary honest person experiences when facing a choice between what is right and what is safe. However, before we explore the text, let us first make use of the technology available today to scan each of the two quick response codes below ${ }^{2}$ and to listen to both versions of the song, concentrating solely on what the music itself communicates:
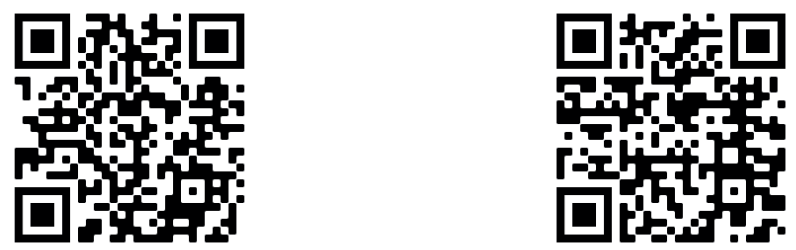

Irrespective of whether one understands Polish or not, the difference between the two performances is striking. While Tomek Opoka's harsh voice against the background of the unsophisticated sound of his guitar communicates existential drama, the close a cappella harmonies of the Banana Boat, conversely, are delusively soothing; they emanate tranquility. Opoka's performance, alluding to the style developed by such master singer-songwriters as Vladimir Vysotsky, Bulat Okudzhava or Jacek Kaczmarski (all of whom would often be compared to Lluís Llach, Bob Dylan, Georges Brassens, or Jacques Brel), suggests that the poem should be read

Captive Minds Normativities and Protests and interpreted with the protest song tradition in mind. The version proposed by Tomasz Czarny and Paweł Konieczny, however, renders Ernest Bryll's lyric stylistically independent of the legacy of the great bards, thereby suggesting a reading context free from the connotations of engagée poetry.

Thus, the two musical arrangements may be claimed to call into existence two different philosophical statements. The first of these may be argued to correspond with the sentiments broadly shared

2. If you are reading the print version of this article, please use the QR scanner application in your cellphone to listen to each of the musical interpretations of the poem, or-if you are reading the pdf version of this text-click on the QR codes or hyperlinks below: Tomasz Opoka's version https://www.youtube.com/watch?v=0X79t8bxajA and Banana Boat's version https://www.youtube.com/watch?v=YEnhfTabt2o (both links are active). 
by the generation of listeners who have experienced the "long 1968." The second one lends itself to being read as an expression of the essence of the "intimate revolt," embodying a reflection on the nature of one's own moral inertia in the world where one may actively participate in a variety of forms of protest without any serious consequences, but too often chooses not to.

Że nauczyłem się
chytrości lisiej
Że umiem mącić tak tropy pogoni
W półprawdy czmychnąć
jak w zeschnięte liście
Do mysiej dziury
by tam się uchronić

Niosę jeszcze swe wiersze, jak kitę płomienia Ale to pożar tylko malowany Niosę też pysk swój rudy, w burzach wyczmuchrany I kłamstwo, co przywarło mi do podniebienia

Że nie zabiłem, to chciałem zabijać Że nie zdradziłem, to byłem jak żmija Co pośrodku trawy próżno się jadowi I nie ma szczęścia, by kogoś ułowić

Niosę jeszcze swe wiersze, jak kitę płomienia Ale to pożar tylko malowany Niosę też pysk swój rudy, w burzach wyczmuchrany I kłamstwo, co przywarło mi do podniebienia
Although l've learnt the slyness of the fox on the run To con the hounds who follow my scent Hiding in half-truths like in fallen leaves I go to ground when the pack won't relent I still carry my poems like a fox brush ablaze Yet the flame is only painted fire And I carry my own red muzzle weathered, uninspired And the lie stuck to my palate so abrasive

Though not a killer I wished to be killing Though not a traitor, I was like a viper who amid tall grasses gnashes poisoned fangs Never to sink them in anyone's shank I still carry my poems like a fox brush ablaze Yet the flame is only painted fire And I carry my own red muzzle weathered, uninspired And the lie stuck to my palate so abrasive ${ }^{3}$

In this first person confession, the lyrical "I" struggles with his painful awareness of the dissonance between the truths romantically proclaimed in his exhortative poems and the "fox-like" survival

3. Translated by Paweł Jędrzejko. 
strategies he has developed to avoid confrontation at all cost. Like a torch, his poetry sets the hearts of his audiences ablaze; it is the bright light dispersing the shadows of despair; it is a beacon of hope; it spells out what others think, but are unable to name; it is a call to which one cannot remain indifferent. The speaking "I" realizes that he is a poet and, like the Romantics before him, he is aware of his own role as the spiritual leader: his vocation is to inspire others. And yet, although his impassioned lyrics do arouse incandescent feelings in his audiences, although his songs, fervent and sublime, do urge individuals to fight the evil, even if it should mean that the community of the fearful would be ransomed with the blood of the brave few, the poet struggles with shame because he feels that he is not within their number and discredits his own poetry as a testimony to his own hypocrisy. Showing his fox-like, cunning face to the world, he hides his real sentiments among half-truths for fear of betrayal or denunciation. Perhaps camouflaging his true colors under the mask of the "safe" newspeak, he lives a lie that, although it has become an inextricable part of his everyday conversations, remains painfully "abrasive." Although himself he has not denounced or betrayed anyone, the poet weighs words that could potentially put him in harm's way, slithering in the underbrush of reality like a viper in the meadow: able to strike when cornered, but instictively driven to run at the first sign of danger. Disap-

Captive Minds Normativities and Protests pointed with his own weakness, he gives in to frustration: like Billy Liar in the machine gun scene of the film, he dreams of killing off all whom he hates, but, realizing that his hand better fits the pen than it does the Molotov cocktail, he suppresses his anger-and slithers on. Whenever in danger, he resorts to his cunning: the "goes to ground" when the relentless hounds pick up his scent.

And yet, at odds with his self-perception as a weakling, his protest burns in the realm of words. Despite all, he still "carries his poems" for others to follow. But although the spectacular "fox brush"the object of desire of fox hunters throughout centuries-bears an uncanny resemblance to a torch ablaze, deep in his heart the poet feels that the flame is "only painted fire," that it is unreal. He feels that while writing poetry, he is not taking any real stance: words, in his view, are not tantamount to tangible action. 
Yet, to all those remembering the "long 1968" it is clear that Bryll's fox-hunt metaphor is not simply a trope: those opposing the oppresive practices of the governments of the time-poets and protesters alike-would, indeed, be hunted down by secret services, state security, or police. Whether anti-communist or anticapitalist, whether anti-Soviet or anti-white supremacist, active resistance at the time carried a very real risk of the first-hand experience of the riot police brutality, imprisonment, torture, or even loss of life. The choices made by those ready to face it were inevitably tragic and thus also their heroism was the heroism of tragic dimensions, even though history would rarely record the names of countless quotidian heroes, whose desperation or rightful wrath would drive them into the streets, irrespective of the price they were likely to pay, and which they often did pay.

The tragic heroism of these individuals is testified to by some of the most iconic photographs of the time, collected, for instance, by Talia Lakritz in her photostory "The Most Iconic Protest Photos of All Time," by Leanna Garfield and Natalie Colarossi in their "20 Photos that Chronicle America's Iconic History of Activism," or in the extensive archives of such organizations as World Press Photo or Magnum Photos. Among countless touching, emotionally charged examples, perhaps the most well known are Malcolm Browne's photo reportage of Thích Quang Đúc self-immolation on June 11,1963 , the photo of the black student being attacked by police dogs at a civil rights demonstration, taken by Bill Hudson on May 3, 1963, Josef Koudelka's photographs of the Warsaw Pact invasion in Prague in August 1968, John Filo's photo of the aftermath of the Kent State shootings on May 1, 1970, or the photographs of a lone man standing up to a line of tanks in Tiananmen Square on June 4,1989 , captured independently by photo reporters Jeff Widener and Stuart Franklin. What these and many other images of the time have in common is the sense of the authenticity: the reality of pain and the immediacy of death dominate the captured scenes not only in terms of the presence of the obvious attributes of oppression (such as police dogs, weapons, or dead bodies), but also in terms of the overwhelming sense of stern determination stemming from endless desperation etched into the sad 
Captive Minds Normativities and Protests or angry faces of the protesters, and unspeakable fear in the eyes of the accidental witnesses, unwilling beholders.

There is no doubt: contemporary images capturing street riots and physical clashes between the police and the protesters carry similar dynamics; certainly, casualties occur today as well as they did in the past decades. Still, today, in the countries of the West, the death of a demonstrator is an accident rather than a norm; armed units no longer invade university campuses shooting students, police no longer raid gay bars to arrest patrons for the display of same-sex affection, and instances of beating or other forms of torture at the police stations or local jails almost always result in more or less publicized protests. While protesters' lives and their essential rights used to matter rather little in the $1960 \mathrm{~s}, 2{ }^{\text {st }}$ century march participants often make their statements by purposefully exposing themselves to being arrested, as if they were certain that their rights would not be violated in jail. Unless, of course, one represents one of the non-privileged groups, in which case such an idea could prove gravely misbegotten, and therefore taking the risk of being arrested requires serious determination and profound awareness of potential consequences.

Examples confirming the above observations could be multiplied. For instance, during the massive Chicago and Los Angeles immigrant-rights protests in 2006, documented, among others, by the photojournalists of the LA Times, the clarity of such a strategy became verbalized in a caption under a photograph taken on Sept. 26, 2006 (which made it to Garfield and Colarossi's top 20 list). The caption reads: "Protesters hold hands as they wait to be arrested by Los Angeles police officers, after refusing to leave a busy thoroughfare near Los Angeles International Airport while demanding unionization of mostly immigrant workers at a dozen high-end hotels in Los Angeles." ${ }^{4}$ Comprehensibly, the statement

4. See: Leanna Garfield and Natalie Colarossi, "20 photos that chronicle America's iconic history of activism," Business Insider, Jun 5, 2020, https://www.businessinsider.com/america-activism-photos2017-2?IR=T\#protests-related-to-immigrant-rights-grew-in-theearly-2000s-in-2006-hundreds-of-thousands-of-people-protestedagainst-anti-immigration-legislation-in-cities-around-the-us-including-los-angeles-and-chicago-13. Accessed 10 June 2020. 
made by the protesters holding hands in a gesture of solidarity is clear: "you cannot imprison us all." And yet, the participants of the action, smiling, elated with the sense of communion, are aware of their safety. They do not await arrest: they wait to be arrested, as if being arrested were a social event, a value added to an otherwise joyful occassion. This observation, certainly, is not to diminish the value of the 2006 immigrant-rights protests, which in fact brought together in excess of 10 thousand protesters and effectively prevented the passing of the oppressive Sensenbrenner bill in the U.S. Senate. ${ }^{5}$ But it does shed some light upon how political activism has changed. Numerous examples demonstrate that arrest, which once was a very serious, and potentially life-threatening, consequence of one's defiance of oppressive rule (as experienced by many peaceful protesters of the Martin Luther King Jr. era), in the western countries of today seems to be little more than mere inconvenience or, in some situations, a politically/socially desired outcome of one's participation in the protest. While in the 1960s, 70 s, and 80 s arrests following sit-ins and other forms of non-violent protest could lead to a long term incarceration, today, in many cases, being arrested "counts" if it has been caught on a smartphone camera and uploaded to social media servers. With exceptions, street protests seem to have come to resemble happenings or theatrical acts rather than being a form of real resistance, for which there could be a very high price to pay.

An interesting case in support of the observation above has been described by Max Cea, who, in his 2017 article "Lemme take a selfie: The art and vanity of protest photography," offers the following reflection on the reality of the Women's March on January 21, 2017:

It's embarrassing to admit now, but attending the Women's March on Washington didn't feel like an entirely safe prospect as late as last Friday afternoon. Hundreds of thousands of people were expected

5. See: H.R.4437-Border Protection, Antiterrorism, and Illegal Immigration Control Act of $2005<$ https://www.congress.gov/bill/109th-congress/house-bill/4437>; see also: Mark Engler and Paul Engler, "Op-Ed: The massive immigrant-rights protests of 2006 are still changing politics," Los Angeles Times, March 4. 2016 <https://www.latimes.com/opinion/ op-ed/la-oe-0306-engler-immigration-protests-2006-20160306-story. html> (Access 10.06.2020). 
to attend. Trump's inauguration rhetoric was divisive, escalating fragile tensions to a new nadir. There were rumblings about paid agitators; and, in fact, there was violence on Friday.

What ensued on Saturday was as peaceful and positive as could have been hoped for given the aforementioned factors and the higher than expected turnout. While it was a claustrophobe's nightmare, it was no radical protest. The most violent act of the day was arguably Madonna saying, "I have thought an awful lot about blowing up the White House" and singing that the new president should "suck a dick"-rhetoric which, it's important to acknowledge, the mainstream media likely would have looked at with more than a shrug if it had come from a cowboy-hatted conservative performer. (Cea)

Quite obviously, despite the ominous clouds of presidential rhetoric gathering over America, which, indeed, would allow anyone aware of the history of the U.S. political activism to realistically forecast a much more stormy reaction of the protesters, the atmosphere of the March itself proves far lighter than anticipated. In fact,

[f]or the most part, the day's mood was closer to a festival or parade than the 1960s protests that have come to define Americans' protest ideal. Because there were so many people and because it was unclear who the leaders were and what the protest's mission was, the main attraction at the Women's March was the signs. Every third person or so waved a sign, and the signs represented a diverse array of issues-the environment ("Clean air = healthy kids"), minority rights ("You can't comb over racism"), and, most of all, women's rights ("This pussy grabs back"). (Cea)

Captive Minds Normativities and Protests

The discrepancy between the "protest ideal" of the 1960 s and the "parade-like" demonstration becomes even more tangible when one considers the participant's secondary goals along with the "fringe benefits" that they enjoy-benefits, which the protests of the previous era technologically could not, but also politically would not, warrant:

To meander or march down Independence Avenue was to see and be seen. Almost everyone acted as a photographer, documenting with a smartphone; and the bearers of the signs with the wittiest messages or most artful designs were constantly being photographed. (Cea)

On the one hand, it is a positive symptom that civic education and the overall increase in social awareness among the western 
populations have resulted in a far greater willingness of present day Americans and Europeans to speak out in support of causes that may not necessarily concern them directly, and that existing legal mechanisms facilitate such choices. The fact that technology makes it possible to record events and that short videos and smartphone snapshots become immediately available to communities growing around social media is also beneficial to the protesters; manipulation of the facts recorded by thousands has become much more demanding and requires the development of far more refined PR strategies on the part of media serving the dominant political factions. However,

There's a cynical way to look at the use of photography at the march-that attending, for some people, was an act of vanity. There's a long history of aestheticizing protesting. In a 1970 New York magazine story, Tom Wolfe satirized how white liberals fetishized the Black Panther Party's "radical chic"-the Afros, militant garb and weapons chosen by the likes of Angela Davis and Huey Newton.

And indeed, many of the photographs published on social media or by news websites used appropriated grainy black and white filters and revolutionary imagery (raised fists and geometric alignment, for instance) to cast Saturday's protest in a radical light. Not only were these photos dishonest depictions; they undermined the burden of being a Vietnam War era or civil rights protester: Protesting and being photographed came with many more risks then than it did on Saturday.

But there were too many photographs for the aesthetic choices of all those taking them to tarnish the effect of the images' whole. The flip side to the mass photographing was that when you look at the \#Womensmarch feeds cumulatively, a more accurate story plays out: The diversity of grievances and sheer mass of bodies frames Trump's detractors not as a persecuted minority but as a persecuted majority. (Cea)

Again, Cea's article-despite its subtly critical edge-does not aim to demean the value or importance of the Women's March. Conversely, in conclusion it presents the overall, global outcome of the event, which gave the observers an impression that "Trump's detractors" are, in fact, in majority, and that this majority feels persecuted. The above notwithstanding, his reflections underscore a few important issues, such as the transformation of political activism from a high-risk form of engagement in the social process to a form of more or less politically-conscious entertainment, 
Captive Minds Normativities and Protests in which it is fashionable to participate, thoughtless appropriation of the ethos of the protesters of the previous era by the photographers of today, or the lack of non-ambivalent focus upon the cause. Conditioned by a diverse array of factors, some of these changes are largely related to the onset of the digital era and the tangibility of the coexistence of the actual and virtual planes of social contact. In the context of social and political activism, this phenomenon has been interestingly theorized by Justin Michael Battin and Elle Rystakova, who, in their article "Heidegger and Fan Activism. Unveiling the Presence of Poiēsis in Contemporary Online Social Mobilization," analyze fan activism in contrast to what they dub "mouse-click solidarity" or "slacktivism." Among others, the authors argue that

The widespread presence of virtual commitments incongruent with action on the ground is symptomatic of a greater issue. According to Herzogenrath-Amelung, modern social media use for activist purposes, with the emphasis on sharing, is increasingly propelled by das Gestell (the framework or enframing), by overt instrumental reasoning. She writes, "Heidegger's concept of enframement [...] allows us to see the passionate Tweets, Facebook profile picture filters and other signals of solidarity in a very different light: as signs that what, according to Heidegger, uniquely characterizes human being-in-the-world has been reduced to a technologized parody." 6 Human beings are currently wading through a rather unique epoch, one driven by an overwhelming adherence to technocratic rationality and instrumental reason. In one of Heidegger's more provocative pieces, he argued that since the philosophy of Plato and its emphasis on detached observation, western society had been steadily progressing towards a world where being had been forgotten. All things, including objects, catastrophes, and even other human beings have completely leveled; they become regarded as mere replaceable stock (Bestand [standing reserve]) and all meaningful distinctions that allow human beings to differentiate what is existentially critical for one's self simply fade away. [...] The overwhelming presence of Das Cestell has led to a serious lack of investment, but also a decline in communal engagement, although the two of course are interconnected. (69)

6. The quotation comes from the following source: Heidi Herzogenrath-Amelung, "Speaking the Unspeakable: Heidegger and Social Media's Mouseclick 'Solidarity,"' in: We Need to Talk About Heidegger: Essays Situating Heidegger in Contemporary Studies. edited by Justin Michael Battin and German A. Duarte. Peter Lang Verlag 2018, p. 159, quoted in Battin and Rystakova (69). 
The above notwithstanding, the authors do not content themselves with diagnosing the present day society as in decline of communal engagement. On the contrary, they see a future in virtual activism, which does not have to automatically be reduced to the level of a parody of the Heideggerian being-in-the-world. In fact, the concurrence of the virtual and the actual in our lives, which is undeniable, opens up a new niche for activism: one that does not replace or eliminate the real-life, actual engagement, but adds an important virtual dimension to it. Beyond doubt, one may choose to fashion oneself as an Internet Hero and remain a slacktivist, but one may also use the social media to organize and document actual protest actions, thereby choosing to leave one's comfort zone.

The comfort, hovever, seems to be fading away. Legislations in many European countries, including Poland and Hungary, have already changed: strict laws protecting politicians against "defamation of character" have been introduced, which practically means that Madonna's bold words uttered during the Women's March on January 21, 2017, if proclaimed publicly in Poland with respect to the Polish president, could land her in jail. The freedom of speech we still enjoy in the western world is being evidently curtailed, and whether we choose to see it or not, the idea of the protest as a "festival" may soon become painfully invalidated by the creeping reality of life in neo-totalitarian regimes.

Our discomfort today, indeed, is still relative. Still, because today we may enjoy the "social occasions" of protest marches, simultaneously "doing the right thing." Ironically, people who lost their lives, who were maimed, incapacitated, or imprisoned in the aftermath of the protests of the 1960s, 70s and 80s, people who were vanished after they had been identified as participants of illegal marches, countless brave individuals who lost their jobs as a consequence of their defiance, a league of artists who would be refused the possibility to practice their art as punishment for their non-conformity, academics who were offered one way tickets abroad-all of them paved the path for us to be able to "rebel safely." And yet, even more ironically, we choose not to act far too often. Our expression of solidarity with underprivileged groups or individuals often takes the form of a mouse-click, as if struggle for gay rights or the rights 

serious consequence of our rebellious actions may be temporary loss of work or income. No one will pull our nails in jail if we are arrested during a peaceful demonstration, no one will sentence us to decades of prison for speaking out against injustice. Yet, if we choose to go to ground now, when no hounds follow our trail, our freedom to protest may come to an end sooner than we think. Ironically, perhaps.

Pawet Jędrzejko

RIAS Associate Editor 
Battin, Justin Michael and Elle Rystakova, "Heidegger and Fan Activism. Unveiling the Presence of Poiēsis in Contemporary Online Social Mobilization," Er(r)go. Theory-Literature-Culture, no. 40 (1/2020), doi: https://doi.org/10.31261/errgo.7560

Bryll, Ernest. "Niosę jeszcze swe wiersze" http://www.tomekopoka. com/dokumenty/piosenki/niose_jeszcze_swe_wiersze.pdf. Accessed 10 June 2020.

Cea, Max. "Lemme take a selfie: The art and vanity pf protest photography. What the \#Womensmarch feeds got right and wrong about the Women's March on Washington."January 25, 2017 https://www.salon.com/2017/01/24/lemme-take-a-selfiewere-awash-in-photos-how-can-protest-images-serve-toinspire-a-new-generation-of-activists. Accessed 15 June 2020.

Garfield, Leanna and Natalie Colarossi. "20 photos that chronicle America's iconic history of activism," Business Insider, Jun 5, 2020, https://www.businessinsider.com/america-activism-photos2017-2?IR=T\#protests-related-to-immigrant-rights-grew-inthe-early-2000s-in-2006-hundreds-of-thousands-of-peopleprotested-against-anti-immigration-legislation-in-citiesaround-the-us-including-los-angeles-and-chicago-13. Accessed 10 June 2020.

Kristeva, Julia. Intimate Revolt. The Powers and Limits of Psychoanalysis.Translated by Jeanine Herman. Columbia University Press, 2003. ISBN 9780231114158 
